\title{
The Influence of Adding GLONASS Signals on Quality of RTK Measurements**
}

\section{Introduction}

The main advantage of navigation satellite techniques over the conventional measurement is the speed and economy of work. Together with a network of reference station GNSS techniques it allows to determine position with accuracy at the centimetre level [1]. The concept of measuring real-time kinematic (RTK - Real Time Kinematic) was established in the mid 90's and the great development of this technique has taken place over the last decade. Two types of corrections can be distinguished in RTK measurements: from a single base station and from a network of reference stations (RTN - Real Time Network). Currently, these types of networks operate in Europe, Asia, Australia and North America. Their sizes vary from 5-6 stations providing support for position systems (e.g. those applied in agriculture) to a network of several hundred of stations of regional range for surveying or engineering applications [2].

In this article the author is trying to determine the effect of adding GLONASS signals on a number of RTK precision solutions with the use of ASG-EUPOS corrections. The measurement was conducted under conditions of limited visibility horizon in urban areas.

\section{ASG-EUPOS}

Multi-functional satellite positioning system ASG-EUPOS (Polish: Aktywna Sieć Geodezyjna EUPOS) was established in 2008. It is one of the ground based augmentation system (GBAS) [3] and also a part of EUPOS (European Position Determination

* AGH University of Science and Technology, Faculty of Mining Surveying and Environmental Engineering, Department of Geomatics, Krakow, Poland

** This paper is the research carried out within statutory research grant no. 11.11.150.006 in the Department of Geomatics, AGH University of Science and Technology, Krakow and within Dean's Grant no. 15.11.150.131 
System) project. In the construction phase it was assumed that ASG-EUPOS will be initially using GPS signals only, whereas in the future, the Galileo system will become its primary signals source, while other navigation satellite systems will only be used as supportive means [4].

The basic assumption and also advantage of the EUPOS project is the use of uniform technical standards for network reference stations of all member countries. This ensures a free exchange of data and projects to be active throughout its entire area. This fact is particularly important in the border areas where solutions are based on observations from neighbouring countries' reference stations [5].

EUPOS stations' coordinates are determined both in ETRS89 and in local, state systems. Each of the stations is equipped with a precise, dual frequency GNSS receiver. Currently there are 122 reference stations operating in ASG-EUPOS (including 38 with GPS+GLONASS module) (Fig. 1); 19 of them belong to EPN or IGS network [6]. These stations are distributed evenly across the country and the average distance between them is $70 \mathrm{~km}$ [7].

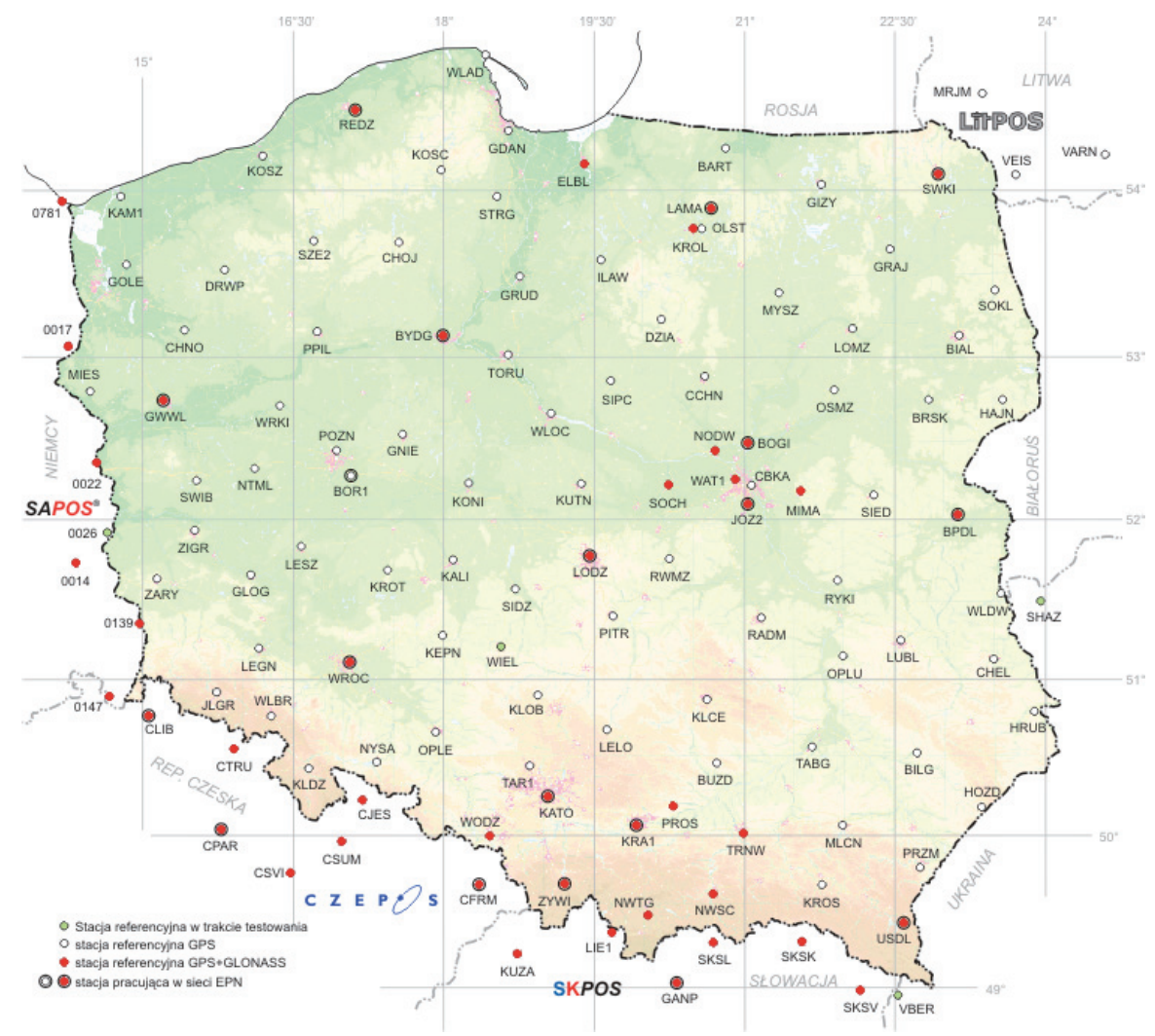

Fig. 1. Distribution of ASG-EUPOS stations Source: http://www.asg-eupos.pl 
The primary objective of establishing ASG-EUPOS was to support surveyors. In the future - in connection with the development of satellite navigation techniques reference stations are going to function as the fundamental geodetic control network [6]. Already today ASG EUPOS is used in a number of other domains relating to e.g. GIS or geodynamic research [8]. Moreover, within ASG-EUPOS numerical weather models are created which allows now a reliable description of the state of the atmosphere and in the near future, due to its high spatial resolution ASG-EUPOS, will allow the construction of a NRT 4D atmosphere model for the area of Poland [9].

Accuracy and precision of RTK solutions depends heavily on terrain conditions, type of used corrections and capabilities of measuring equipment. ASG-EUPOS, used in a proper way, allows for the performance of geodetic measurements of very high accuracy. A very important element of the RTK measurement is the so called initialization, where a receiver determines its initial (starting) position. There is a probability, though small, that the GNSS receiver will perform faulty initialization which will cause the displacement of all points measured in session. Therefore, in measurements done with real-time ASG-EUPOS services it is still recommended to control measurements on points with known coordinates [3].

\section{ASG-EUPOS Services}

ASG-EUPOS currently offers five different services dedicated to work on satellite observations which differ in methods of compiling data and accuracies possible to achieve. A full list of all ASG-EUPOS services with accuracies possible to obtain and hardware requirements are presented in Table 1.

Table 1. ASG-EUPOS services

\begin{tabular}{|c|c|c|c|c|c|}
\hline $\begin{array}{c}\text { Type of } \\
\text { measurement }\end{array}$ & Name & $\begin{array}{l}\text { Measure- } \\
\text { ment } \\
\text { technique }\end{array}$ & $\begin{array}{c}\text { Data } \\
\text { transmission }\end{array}$ & Accuracy & $\begin{array}{l}\text { Minimum hardware } \\
\text { requirements }\end{array}$ \\
\hline \multirow{3}{*}{$\begin{array}{l}\text { Real-time } \\
\text { services }\end{array}$} & NAWGEO & $\begin{array}{l}\text { kinematic } \\
\text { (RTK) }\end{array}$ & \multirow{3}{*}{$\begin{array}{l}\text { Internet, } \\
\text { GSM (GPRS) }\end{array}$} & $\begin{array}{l}\text { up to } 0.03 \mathrm{~m} \\
\text { (horizontal) } \\
\text { up to } 0.05 \mathrm{~m} \\
\text { (vertical) }\end{array}$ & $\begin{array}{l}\mathrm{L} 1 / \mathrm{L} 2 \text { receiver, } \mathrm{RTK} \text {, } \\
\text { communication port }\end{array}$ \\
\hline & KODGIS & kinematic & & up to $0.25 \mathrm{~m}$ & \multirow{2}{*}{$\begin{array}{l}\text { L1 receiver DGPS, } \\
\text { communication port }\end{array}$} \\
\hline & NAWGIS & (DGPS) & & up to $3.0 \mathrm{~m}$ & \\
\hline \multirow{2}{*}{$\begin{array}{l}\text { Post } \\
\text { processing } \\
\text { services }\end{array}$} & POZGEO & static & \multirow[b]{2}{*}{ Internet } & \multirow[b]{2}{*}{$0.01-0.10 \mathrm{~m}$} & \multirow[b]{2}{*}{ L1 receiver } \\
\hline & POZGEO D & $\begin{array}{l}\text { static, } \\
\text { kinematic }\end{array}$ & & & \\
\hline
\end{tabular}

Source: http://www.asgeupos.pl/ 
Three types of network corrections are available as a part of NAWGEO service: VRS [12], FKP [13] and MAC [14]. Their flowchart is shown in Figure 2. Currently, NAWGEO provides only VRS and MAC corrections; due to a very small number of users FKP corrections were turned off in July 2011 [24].

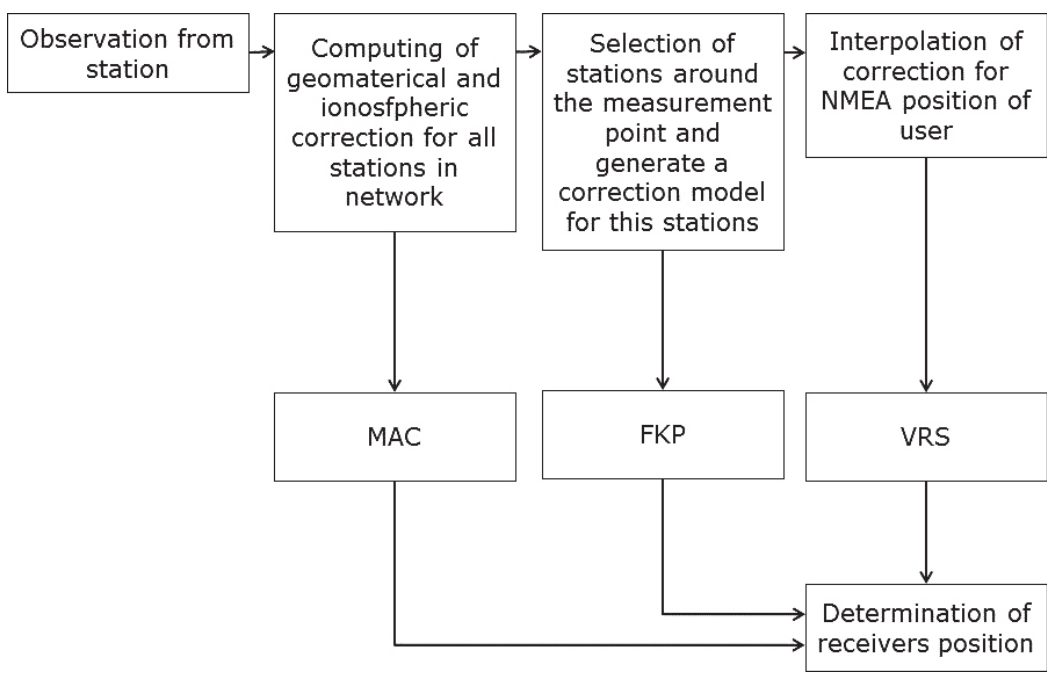

Fig. 2. Operating diagram of network corrections Source: [3]

GLONASS has been fully operational since December 2011 [15, 16]. Since April 2011 GPS+GLONASS network corrections for the area of Śląsk-Małopolska and Mazowsze are available in ASG-EUPOS (Fig. 3).

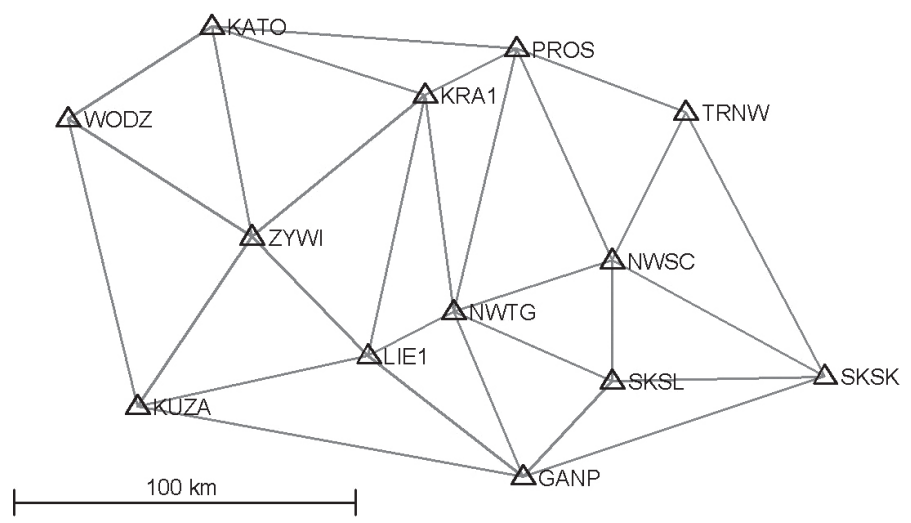

Fig. 3. Reference stations of Śląsk-Małopolska ASG-EUPOS sub network Source: http://www.asg-eupos.pl 
Only for the two metropolitan areas mentioned above it is possible to use GNSS (GPS+GLONASS) network corrections. In the case of GNSS corrections from a single base station, they are made accessible from each station equipped with a GPS+GLONASS module.

The most precise of all ASG-EUPOS real-time services is NAWGEO which provides measurements of accuracy at the centimetre level [10]. As confirmed by research, NAWGEO provides accuracy of $\pm 3 \mathrm{~cm}$ horizontally and $\pm 5 \mathrm{~cm}$ vertically [11]. Also, in the paper [10] it was proved that, within a small distance from reference station, highly accurate results are also obtainable from single base station corrections (2-3 cm for $X Y$, and $5 \mathrm{~cm}$ for height) [10]. Similar results were obtained in a study [22] where differences between multiple determinations of ellipsoidal height with the use of RTK for the same point were ranged within $7 \mathrm{~cm}$.

\section{GLONASS}

Russian navigation satellite system GLONASS (Globalnaya Navigatsionnaya Sputnikovaya Sistema) was founded in the mid-70s as a response to American GPS. The first GLONASS satellite was put into orbit in 1982 and the system became for the first time fully operational in 1995 [17]. However, due to the financial problems of the Russian Federation and relatively short lifetime of the first block of satellites this state was maintained for a very short period of time [18]. GLONASS became fully operational again in 2011, therefore it was only in recent years where there has been a significant development of the system user segment.

The construction and the principle of operation of GPS and GLONASS satellite navigation systems (Figs 4, 5) are very similar to each other.

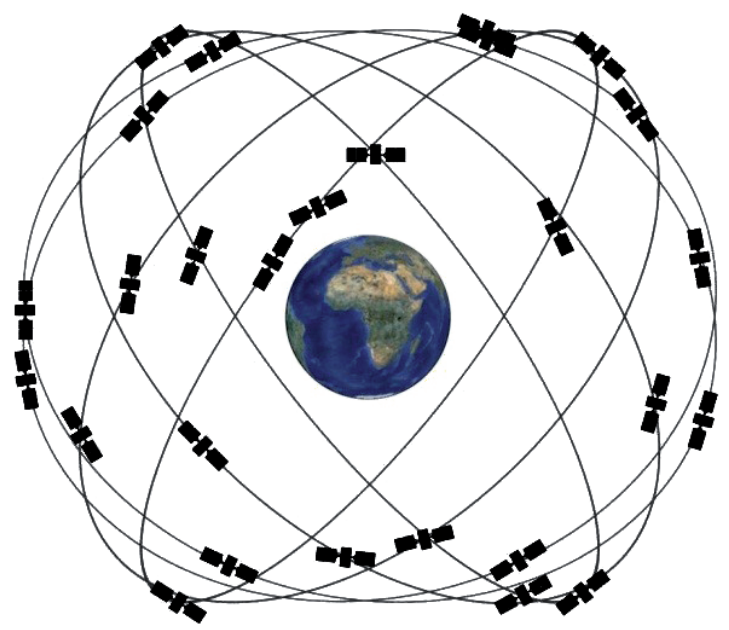

Fig. 4. Space segment of GPS

Source: http://www.gps.gov 


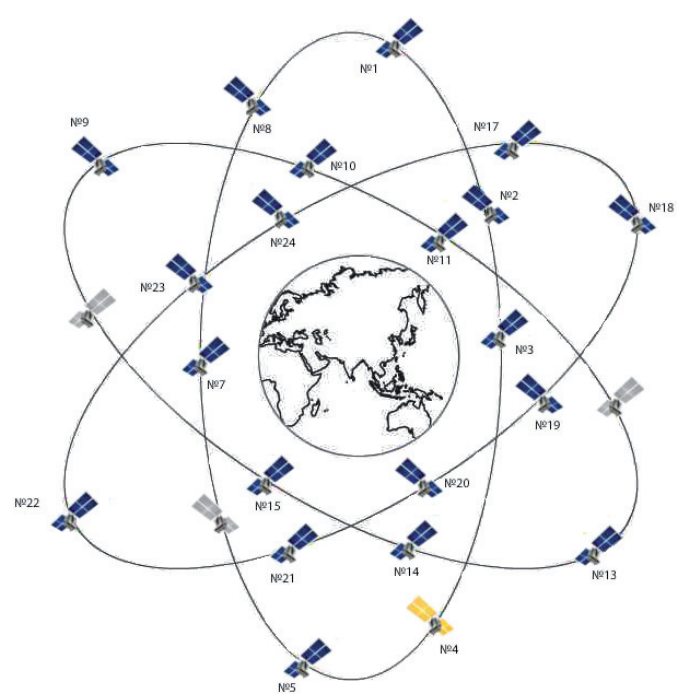

Fig. 5. Space segment of GLONASS

Source: http://www.navipedia.net

Both systems nominally consist of 24 satellites. GPS satellites are unevenly distributed in 6 orbits with 4 satellites (Fig. 4), while GLONASS satellites are distributed evenly, with 8 satellites on each of the 3 orbits (Fig. 5). The main differences between both systems are reference frames, timescale and methods of signal transmission [19].

High angle of orbital plane inclination of GLONASS satellites provides better coverage at high latitudes areas in relation to GPS satellites.

While GPS tracking stations are distributed uniformly over equatorial latitudes providing for the continuous monitoring of each of the satellites, GLONASS's tracking stations are located only in the area of Russia, that causing deficiencies in continuity of tracking [20]. This leads to the formation of errors that, undetected in time, may influence the accuracy of real-time solutions.

Adding supplementary GLONASS observations to the existing GPS signals involves a number of benefits [19]. First of all there are a greater number of observations which may positively influence the accuracy and the quality of the obtained solutions. Moreover, the use of two or more satellite systems allows for the application of autonomous solutions and comparing them. Both satellite systems also allow for reducing the time of a measurement session due to the faster gathering of observations in the same time interval. Moreover, in the case of real-time measurements a greater number of satellites can result in the shorter initialization time of a receiver and the increase of the measurement reliability [21]. Also, the use of additional satellite signals allows for conduction of RTK measurements in the areas, where due to large obstacles it was not practicable. 


\section{Measurement Technology}

In the complex of AGH University of Science and Technology in Krakow measurements using RTK GNSS corrections of NAWGEO service were made. For this purpose, a network of four pairs of points (Fig. 6) located in the areas with large terrain obstacles (Tab. 2) on the campus (urban area) was founded. Points' coordinates were determined in dual, synchronous 4-hour static measurement.

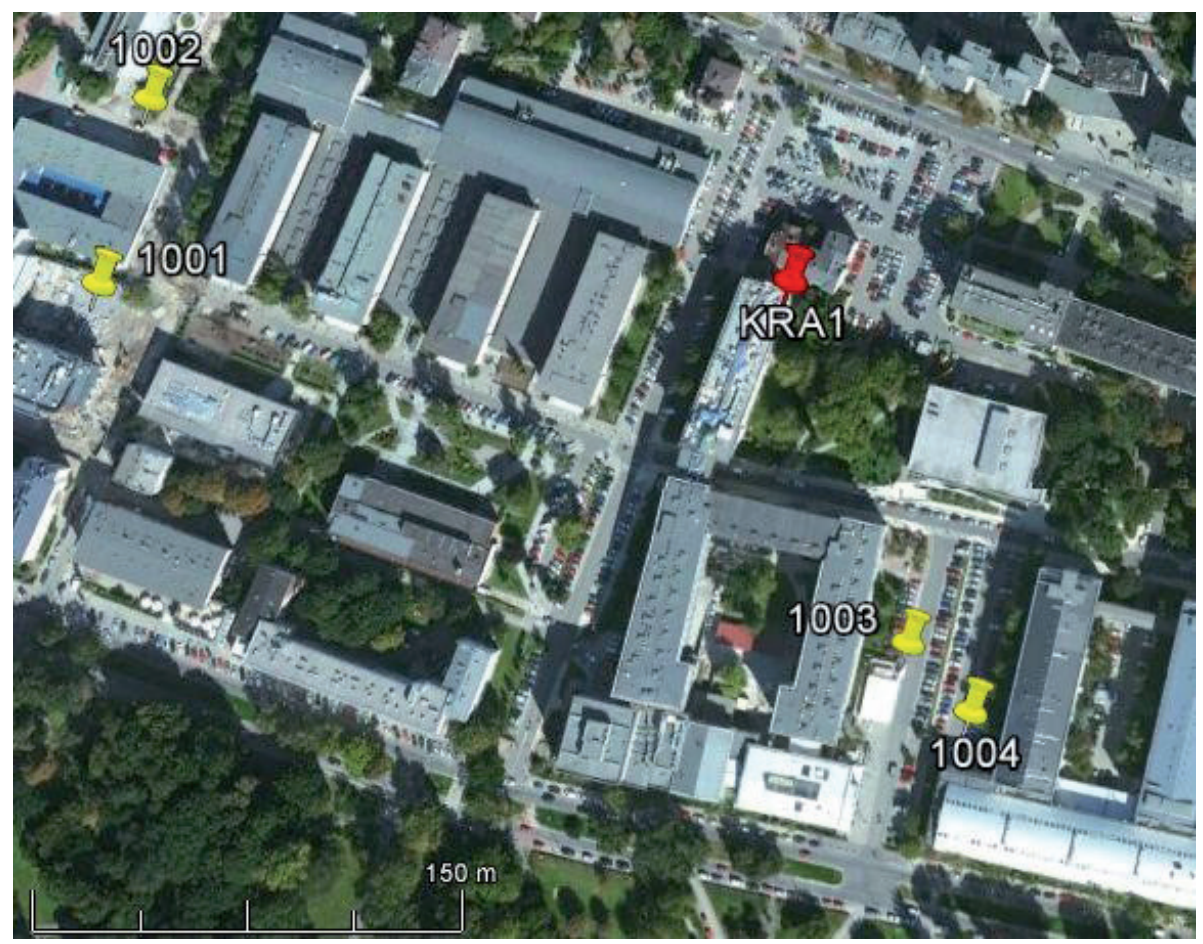

Fig. 6. Distribution of points network against KRA1 station Source: GoogleEarth

Data in Table 2 shows the percentage number of obstacles per each pair of points.

Table 2. Obstacles on each of the points in the network (in percentage values)

\begin{tabular}{|c|c|c|c||}
\hline 1001 & 1002 & 1004 & 1005 \\
\hline $44.98 \%$ & $54.35 \%$ & $48.03 \%$ & $54.65 \%$ \\
\hline
\end{tabular}


Figure 7 shows the exemplary values of terrain obstacles for the 1002a and $1002 \mathrm{~b}$ pair of points.

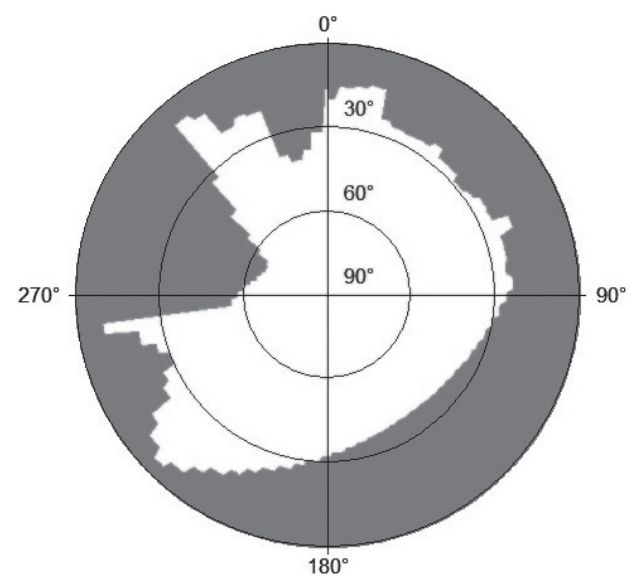

Fig. 7. Size of obstacles for1002a and 1002b pair of points

For every pair of points measurement was performed with use of two GNSS receivers where one worked in GPS mode and the second additionally used GLONASS (GNSS corrections). For the measurement, a set of GNSS Javad Triumph-1 receivers was used. Points in pairs were located 1.0-1.5 $\mathrm{m}$ from each other (Figs 8, 9).

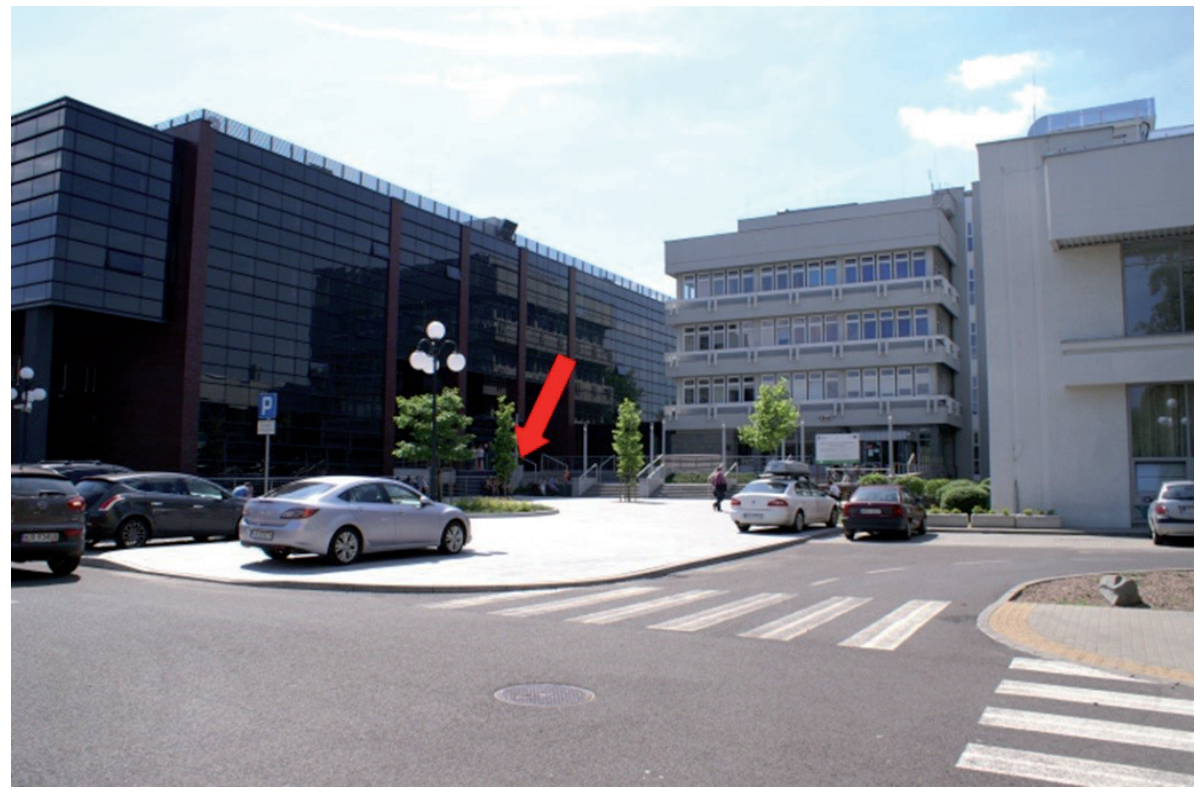

Fig. 8. Location of 1001a and 1001b points 


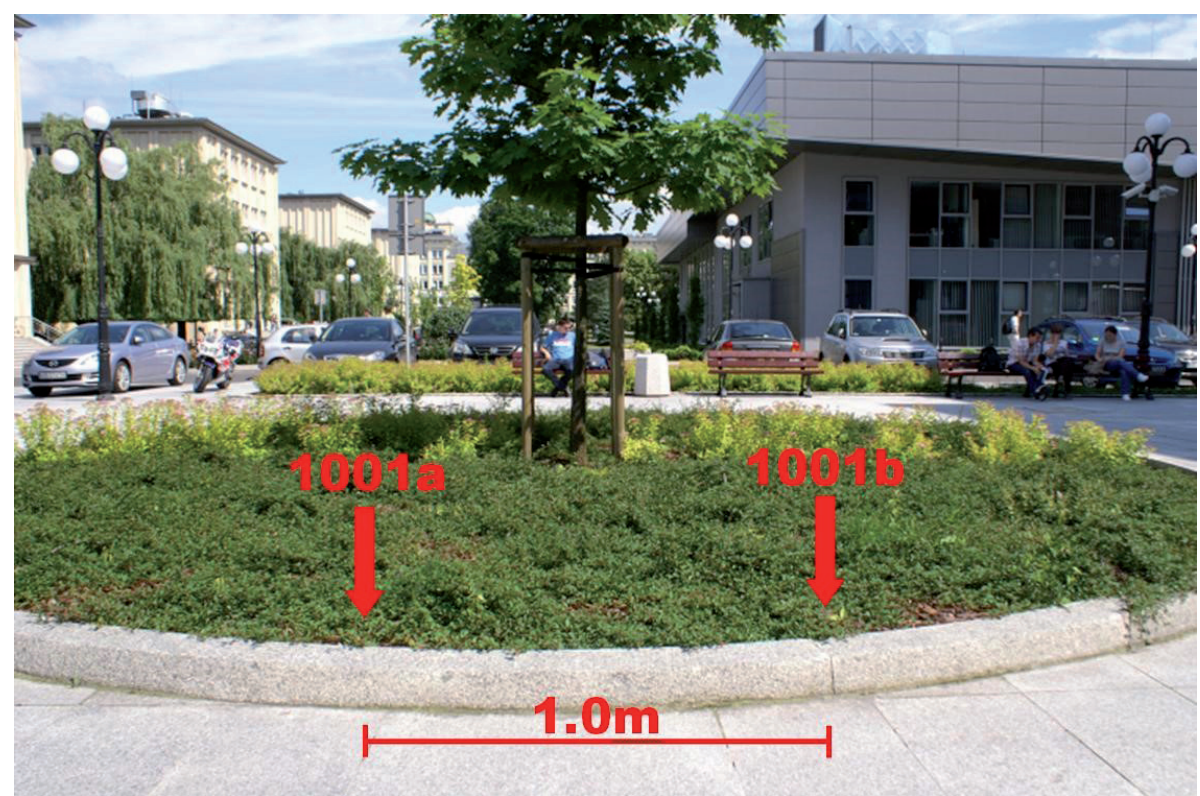

Fig. 9. Points 1001a (GPS) and 1001b (GNSS)

At each of the points RTK measurements were made with the use of network corrections (VRS 3.1) and corrections from a single base station (KRA1 - located 140-260 m away, PROS - $30 \mathrm{~km}$, KATO - $66 \mathrm{~km}$ ) of NAWGEO service. Thus, on each pair of points four different solutions in combination GPS and GNSS (GPS+GLONASS) were applied. Observations in hour sessions with 5 seconds intervals were analysed, whereby the aim was to determine the effect of adding GLONASS observations on the number of precise solutions. Results of ellipsoidal height changes at each point are shown in Figure 8. The calculated coordinates were divided according to the type of obtained solution: fixed ambiguity resolution (fix), float ambiguity (flo) and standard, navigation solution (std).

\section{Results}

For each of the points the number and type of solutions using each of the corrections were presented. Also, the percentage share of each type of solution was provided. The results are shown in Tables 3-6 and in Figure 10 [23].

Table 3 is a summary of particular solutions for the pair of points 1001 . In the case of VRS corrections and those from KRA1 station $100 \%$ of precise solutions for both cases were obtained throughout the entire period. In the case of 1001-PROS vector, GPS signals gave better results - the number of precise solutions was higher than in GNSS. 

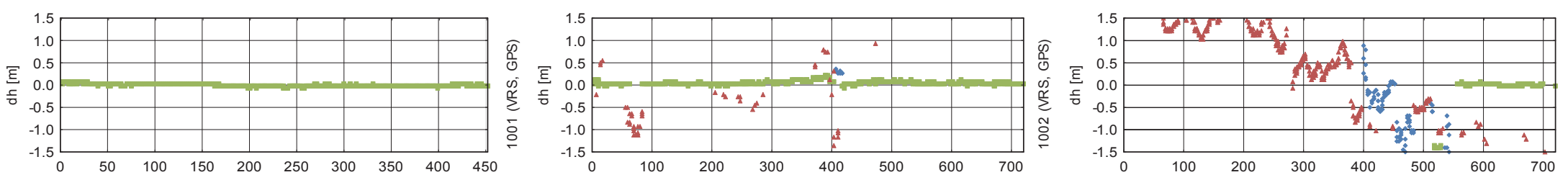

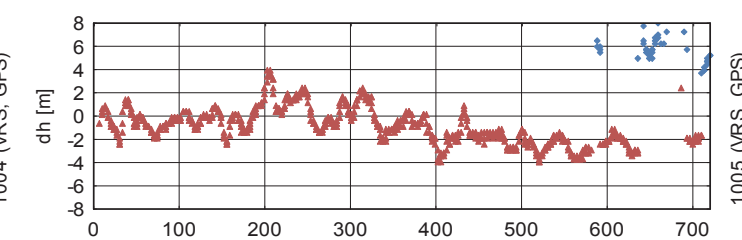
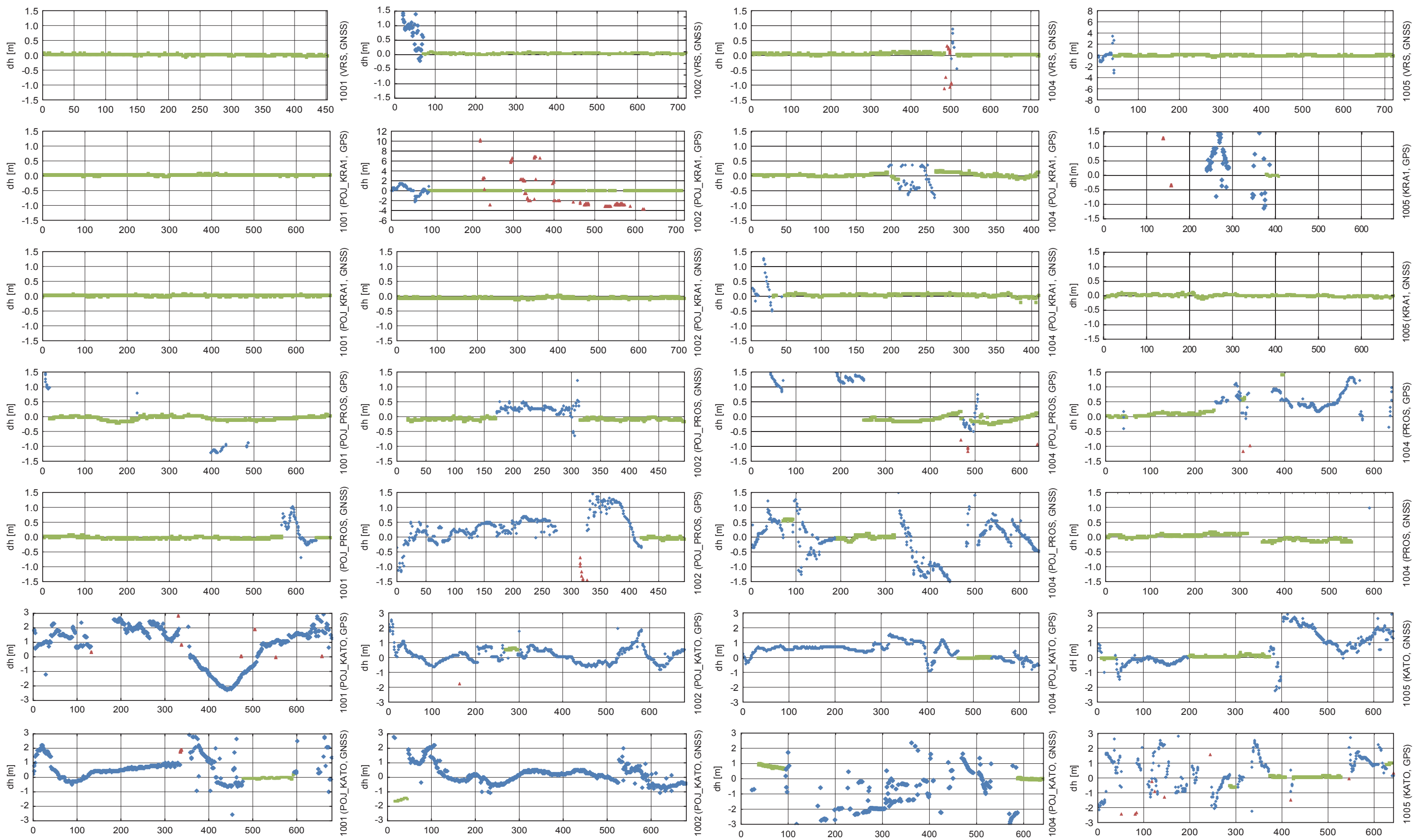

Legend $=$ fix $*$ flo 4 std

Fig. 10. Time series of points' height changes broken down by solution type (VRS - network solution, POJ_XXXX - solution using a single reference station) 
For the longest vector KATO-1001 the GNSS measurements worked better, as the precise solutions were obtained $(17.2 \%)$, which was not the case while using GPS.

Table 3. Comparison of solutions for point 1001

\begin{tabular}{|c|c|c|c|c|c|c|c|c|c|c|c|c|c|c|c|c|c|}
\hline \multirow{3}{*}{$\begin{array}{l}\vec{Z} \\
\text { ठ }\end{array}$} & \multirow{3}{*}{ 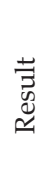 } & \multicolumn{4}{|c|}{ KRA1 } & \multicolumn{4}{|c|}{ PROS } & \multicolumn{4}{|c|}{ KATO } & \multicolumn{4}{|c|}{ VRS } \\
\hline & & \multicolumn{2}{|c|}{ GPS } & \multicolumn{2}{|c|}{ GNSS } & \multicolumn{2}{|c|}{ GPS } & \multicolumn{2}{|c|}{ GNSS } & \multicolumn{2}{|c|}{ GPS } & \multicolumn{2}{|c|}{ GNSS } & \multicolumn{2}{|c|}{ GPS } & \multicolumn{2}{|c|}{ GNSS } \\
\hline & & \# & [\%] & $\#$ & [\%] & $\#$ & {$[\%]$} & $\#$ & [\%] & \# & {$[\%]$} & \# & {$[\%]$} & \# & [\%] & \# & {$[\%]$} \\
\hline \multirow{3}{*}{$\bar{\varnothing}$} & fix & 685 & 100.0 & 685 & 100.0 & 637 & 93.7 & 599 & 88.1 & 0 & 0.0 & 117 & 17.2 & 452 & 100.0 & 452 & 100.0 \\
\hline & flo & 0 & 0.0 & 0 & 0.0 & 42 & 6.2 & 81 & 11.9 & 661 & 97.2 & 560 & 82.4 & 0 & 0.0 & 0 & 0.0 \\
\hline & std & 0 & 0.0 & 0 & 0.0 & 1 & 0.1 & 0 & 0.0 & 19 & 2.8 & 3 & 0.4 & 0 & 0.0 & 0 & 0.0 \\
\hline
\end{tabular}

At point 1002 (Tab. 4) with more than 54\% of horizon obstacles in each case a greater number of precise solutions was obtained when GNSS signals were used. For vector KRA1-1002 100\%, precise solutions were gained for GNSS, in the case of GPS a part of the recorded measurements were obtained in the float or standard mode. For the vector 1002-PROS in the GPS measurement only $10 \%$ precise solutions were obtained (with GNSS nearly 50\%), the rest were mostly float solutions. For the longest vector 1002-KATO, the obtained results were almost the same for both combinations of signals.

Table 4. Comparison of solutions for point 1002

\begin{tabular}{|c|c|c|c|c|c|c|c|c|c|c|c|c|c|c|c|c|c|}
\hline \multirow{3}{*}{$\mid \begin{array}{l}\vec{z} \\
\overrightarrow{0} \\
0\end{array}$} & \multirow{3}{*}{ 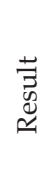 } & \multicolumn{4}{|c|}{ KRA1 } & \multicolumn{4}{|c|}{ PROS } & \multicolumn{4}{|c|}{ KATO } & \multicolumn{4}{|c|}{ VRS } \\
\hline & & \multicolumn{2}{|c|}{ GPS } & \multicolumn{2}{|c|}{ GNSS } & \multicolumn{2}{|c|}{ GPS } & \multicolumn{2}{|c|}{ GNSS } & \multicolumn{2}{|c|}{ GPS } & \multicolumn{2}{|c|}{ GNSS } & \multicolumn{2}{|c|}{ GPS } & \multicolumn{2}{|c|}{ GNSS } \\
\hline & & \# & {$[\%]$} & \# & {$[\%]$} & $\#$ & {$[\%]$} & \# & {$[\%]$} & $\#$ & {$[\%]$} & $\#$ & {$[\%]$} & $\#$ & {$[\%]$} & $\#$ & {$[\%]$} \\
\hline \multirow{3}{*}{ ઠิ } & fix & 520 & 72.9 & 713 & 100 & 74 & 10.9 & 334 & 49.1 & 29 & 4.3 & 29 & 4.3 & 641 & 89.0 & 651 & 90.4 \\
\hline & flo & 92 & 12.9 & 0 & 0.0 & 593 & 87.2 & 346 & 50.9 & 650 & 95.6 & 651 & 95.7 & 9 & 1.3 & 69 & 9.6 \\
\hline & std & 101 & 14.2 & 0 & 0.0 & 13 & 1.9 & 0 & 0.0 & 1 & 0.1 & 0 & 0.0 & 70 & 9.7 & 0 & 0.0 \\
\hline
\end{tabular}

At point 1004 (Tab. 5) with $48 \%$ of the horizon obstacle a more precise solution was obtained for the GPS signals than the GNSS only in the case of the PROS station. For the other corrections, use of the GNSS signals gave better results which is particularly evident in VRS solutions, where over 95\% were precise in GNSS vs 20\% obtained with GPS. 
Table 5. Comparison of solutions for point 1004

\begin{tabular}{|c|c|c|c|c|c|c|c|c|c|c|c|c|c|c|c|c|c|}
\hline \multirow{3}{*}{$\begin{array}{l}\overrightarrow{7} \\
0 \\
2\end{array}$} & \multirow{3}{*}{ 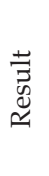 } & \multicolumn{4}{|c|}{ KRA1 } & \multicolumn{4}{|c|}{ PROS } & \multicolumn{4}{|c|}{ KATO } & \multicolumn{4}{|c|}{ VRS } \\
\hline & & \multicolumn{2}{|c|}{ GPS } & \multicolumn{2}{|c|}{ GNSS } & \multicolumn{2}{|c|}{ GPS } & \multicolumn{2}{|c|}{ GNSS } & \multicolumn{2}{|c|}{ GPS } & \multicolumn{2}{|c|}{ GNSS } & \multicolumn{2}{|c|}{ GPS } & \multicolumn{2}{|c|}{ GNSS } \\
\hline & & $\#$ & {$[\%]$} & $\#$ & {$[\%]$} & $\#$ & {$[\%]$} & $\#$ & [\%] & \# & {$[\%]$} & $\#$ & {$[\%]$} & $\#$ & {$[\%]$} & $\#$ & {$[\%]$} \\
\hline \multirow{3}{*}{$\underset{-}{\stackrel{0}{0}}$} & fix & 352 & 85.9 & 364 & 88.8 & 360 & 56.1 & 186 & 29.0 & 71 & 11.1 & 112 & 17.4 & 141 & 19.6 & 688 & 95.6 \\
\hline & flo & 57 & 13.9 & 41 & 10.0 & 275 & 42.8 & 455 & 70.9 & 571 & 88.9 & 530 & 82.6 & 109 & 15.1 & 15 & 2.1 \\
\hline & std & 1 & 0.2 & 5 & 1.2 & 7 & 1.1 & 1 & 0.2 & 0 & 0.0 & 0 & 0.0 & 470 & 65.3 & 17 & 2.4 \\
\hline
\end{tabular}

At point 1005 (Tab. 6) with a value of 55\% horizon obstruction in all of the cases significantly more accurate solutions were obtained with use of GNSS signals. This is particularly evident in VRS and KRA1 station's corrections. For each GPS solution there were some standard solutions of the lowest precision, which were not observed in the case of the GNSS solutions.

Table 6. Comparison of solutions for point 1005

\begin{tabular}{|c|c|c|c|c|c|c|c|c|c|c|c|c|c|c|c|c|c|}
\hline \multirow{3}{*}{ 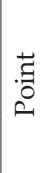 } & \multirow{3}{*}{ 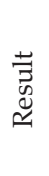 } & \multicolumn{4}{|c|}{ KRA1 } & \multicolumn{4}{|c|}{ PROS } & \multicolumn{4}{|c|}{ KATO } & \multicolumn{4}{|c|}{ VRS } \\
\hline & & \multicolumn{2}{|c|}{ GPS } & \multicolumn{2}{|c|}{ GNSS } & \multicolumn{2}{|c|}{ GPS } & \multicolumn{2}{|c|}{ GNSS } & \multicolumn{2}{|c|}{ GPS } & \multicolumn{2}{|c|}{ GNSS } & \multicolumn{2}{|c|}{ GPS } & \multicolumn{2}{|c|}{ GNSS } \\
\hline & & $\#$ & {$[\%]$} & $\#$ & {$[\%]$} & $\#$ & {$[\%]$} & $\#$ & {$[\%]$} & \# & {$[\%]$} & \# & {$[\%]$} & $\#$ & {$[\%]$} & \# & {$[\%]$} \\
\hline \multirow{3}{*}{ 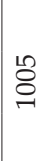 } & fix & 258 & 38.2 & 675 & 100 & 262 & 38.2 & 552 & 80.5 & 171 & 25.1 & 209 & 30.7 & 0 & 0.0 & 675 & 93.8 \\
\hline & flo & 103 & 15.3 & 0 & 0.0 & 256 & 37.3 & 134 & 19.5 & 495 & 72.8 & 471 & 69.3 & 69 & 9.6 & 45 & 6.3 \\
\hline & std & 314 & 46.5 & 0 & 0.0 & 168 & 24.5 & 0 & 0.0 & 14 & 2.1 & 0 & 0.0 & 651 & 90.4 & 0 & 0.0 \\
\hline
\end{tabular}

Summarizing the number of precise solutions obtainable for each of the points and type of correction the positive effects of adding GLONASS observation could have been observed. Only a small number of results obtained with GPS signals gave a greater number of solutions potentially more accurate than in the case of GNSS. As shown in the studies, precise solutions (GPS and GNSS) allow us to determine 3D position with the accuracy of about $3 \mathrm{~cm}$, float solutions with the accuracy of a few $\mathrm{cm}$ and standard (code, navigation) solutions of a few meters.

\section{Summary}

Adding extra GLONASS observations to existing GPS gives one the ability to track more navigation satellites which may potentially increase the quality and accuracy of the solutions. For each of the analysed VRS correction cases, the number of precise solutions was greater or equal in comparison to GPS solutions. Similarly, 
for the shortest vector (KRA1) for each of the points same or more precise solutions were obtained with the use of GNSS signals. For the longest vector (KATO) additional GLONASS observations enabled the obtaining of more accurate solutions. Only in the case of the (PROS) vector, which was an average length vector, the use of GPS observations provided more accurate solutions for some of the points.

To sum up, in the areas where large obstructions exist, RTK solutions with the use of GNSS signals enable us to obtain more accurate solutions than in the case of GPS signals. This has been confirmed by the results obtained for both: corrections from a single base station and network solutions.

\section{References}

[1] Bosy J., Jaworski D.: ASG-EUPOS zdaje egzamin. Geodeta, nr 10, 2008, pp. 22-26.

[2] Stephenson S., Meng X., Moore T.: Precision of Network Real Time Kinematic Positioning for Intelligent Transport Systems. European Navigation Conference 2011, London 2011.

[3] Wajda S.: Podstawowe pojęcia zwiazane z pomiarami satelitarnymi w systemie ASG-EUPOS. Szkolenie Służby Geodezyjnej i Kartograficznej, Zegrze 2011.

[4] Oruba A., Ryczywolski M., Wajda S.: Stawiamy na rozwój ASG-EUPOS. Geodeta, nr 21, 2011, pp. 4-7.

[5] Krzeszowski K., Bosy J.: ASG-EUPOS w terenach przygranicznych. Acta Scientiarum Polonorum. Geodesia et Descriptio Terrarum, vol. 10, 2011, pp. 33-41.

[6] Bosy J.: ASG-EUPOS i podstawowa osnowa geodezyjna. Konferencja Komisji Satelitarnej KBKiS PAN, 2008, pp. 20-21.

[7] Plewako M.: Wptyw dtugości czasu pomiaru technika RTK GPS w systemie ASG-EUPOS na dokładność wyznaczania wspótrzędnych punktu. Infrastruktura i Ekologia Terenów Wiejskich, nr 2/IV, 2012, pp. 99-104.

[8] Krynski J., Rogowski J.B.: National report of Poland to EUREF 2011. Symposium of the IAG Subcommission for Europe, Chisinau, Moldova, 2011.

[9] Bosy J., Rohm W., Borkowski A., Sierny J., Figurski M., Kroszczyński K., Oruba A.: Wykorzystanie systemu ASG-EUPOS w meteorologii GNSS. Konferencja Komisji Satelitarnej KBKiS PAN, Warszawa 2009.

[10] Kudrys J., Krzyżek R.: Analysis of coordinates time series obtained using the NAWGEO service of the ASG-EUPOS system. Geomatics and Environmental Engineering, vol. 5, no. 4, 2011, pp. 39-46.

[11] Figurski M., Szołucha M., Bosy J.: System ASG-EUPOS w zastosowaniach cywilnych $i$ militarnych. III Konferencja nt. "Wykorzystanie współczesnych zobrazowań satelitarnych, lotniczych i naziemnych dla potrzeb obronności kraju i gospodarki narodowej" i VIII Konferencja użytkowników oprogramowania Erdas Imagine i LPS, Serock k. Warszawy 2008. 
[12] Vollath U., Landau H., Chen X.: Network RTK - Concept and Performance. Proceedings of the GNSS Symposium, Wuhan, China, 2002.

[13] Wübbena G., Bagge A.: RTCM Message Type 59-FKP for transmission of FKP. 2002.

[14] Brown N., Geisler I., Troyer L.: RTK rover performance using the Master-Auxiliary Concept. Journal of Global Positioning Systems, vol. 5, 2006, pp. 135-144.

[15] JSC: GLONASS becomes fully operational. [on-line:] http://www.iss-reshetnev.com/?cid=news\&nid=217.

[16] Davydov V., Revnivykh S.: Directions 2013: GLONASS Today and Tomorrow. GPS World, 2012, [on-line]: www.gpsworld.com/directions-2013-glonass-today-and-tomorrow/ [access: 19.12.2014].

[17] Dvorkin V., Nosenko Y., Urlichich Y., Finkel'shtein M.: The Russian global navigation satellite program. Herald of the Russian Academy of Sciences, vol. 79, 2009, pp. 7-13.

[18] Polischuk G.M., Revnivykh S.: Status and development of GLONASS. Acta Astronautica, vol. 54, 2004, pp. 949-955.

[19] Kleusberg A.: Comparing GPS and GLONASS. GPS World, vol. 1 (6), 1990, pp. 52-54.

[20] Polischuk G.M., Kozlov V.I., Ilitchov V.V, Kozlov A.G., Bartenev V., Kossenko V.E., Anphimov N.A., Revnivykh S., Pisarev S.B., Tyulyakov A.E., Shebshaevitch B.V, Basevitch A.B., Vorokhovsky Y.L.: The Global Navigation Satellite System GLONASS: Development and Usage in the 21st Century. 34th Annual Precise Time and Time Interval (PTTI) Systems and Applications Meeting, Reston, Virginia US, 2002, pp. 151-160.

[21] Henning W.: User Guidlines for Single Base Real Time GNSS Positioning. 2011 [on-line:] www.ngs.noaa.gov/PUBS_LIB/NGSRealTimeUserGuidlines.v2.1.pdf [access: 19.12.2014].

[22] Hadaś T., Bosy J.: Niwelacja satelitarna z wykorzystaniem serwisu NAWGEO systemu ASG-EUPOS. Acta Scientiarum Polonorum. Geodesia et Descriptio Terrarum, vol. 8, 2009, pp. 53-66.

[23] Maciuk K.: Integracja systemów GPS I GLONASS w precyzyjnych opracowaniach pomiarów satelitarnych. Kraków 2014 [Ph.D. thesis, unpublished].

[24] ASG-EUPOS, www.asgeupos.pl. 